\title{
Discrimination between domoic-acid-producing and nontoxic forms of the diatom Pseudonitzschia pungens using immunofluorescence
}

\author{
S. S. Bates ${ }^{1}$, C. Léger ${ }^{1}$, B. A. Keafer ${ }^{2}$, D. M. Anderson ${ }^{2}$ \\ ${ }^{1}$ Department of Fisheries and Oceans, Gulf Fisheries Centre, PO Box 5030, Moncton, New Brunswick, Canada E1C $9 B 6$ \\ ${ }^{2}$ Biology Department, Woods Hole Oceanographic Institution, Woods Hole, Massachusetts 02543, USA
}

\begin{abstract}
Separate polyclonal antibodies were developed against cell surface antigens of the 2 forms of the pennate diatom Pseudonitzschia (previously known as Nitzschia) pungens, i.e. forma multiseries (the domoic-acid-producing form) and forma pungens (the nontoxic form). Positive antigenic reactions were visualized with epifluorescence microscopy, using a fluorescein isothiocyanate (FITC) indirect immunofluorescence assay. The assay successfully distinguished 31 clones of $\mathrm{f}$. multiseries from the 17 clones of $\mathrm{f}$. pungens tested, with no cross reactions of the antisera between the 2 forms. The antisera were active against $P$. pungens cells isolated from Prince Edward Island and Nova Scotia, Canada, and Massachusetts, Rhode Island, Texas and Washington, USA. Of the 27 other clones tested from the genera Pseudonitzschia and Nitzschia, 2 other domoic-acid-producing species $(P$. australis and $P$. pseudodelicatissima) and 2 nontoxic species ( $P$. subcurvata and $P$. fraudulenta) showed a slight positive response to the antisera, as did the domoic-acid-producing pennate diatom Amphora coffaeiformis. These reactions are not great enough to cause concern about misidentification, but pose questions about phylogenic relationships. Other representatives from the class Bacillariophyceae and from 8 other major classes of phytoplankton did not cross react with the antisera. Excellent labelling was obtained with live cells and those frozen at $-60^{\circ} \mathrm{C}$, or preserved in $2 \%$ glutaraldehydeparaformaldehyde, $2 \%$ borate-buffered formalin or $2 \%$ paraformaldehyde. Immunofluorescence shows great promise as a technique to distinguish between the 2 forms of $P$. pungens for research and monitoring purposes.
\end{abstract}

\section{INTRODUCTION}

In December 1987, an outbreak of food poisoning due to the consumption of mussels Mytilus edulis from Prince Edward Island (PEI), Canada, resulted in 3 deaths and 107 cases of illness (Todd 1993). The syndrome is called Amnesic Shellfish Poisoning (ASP) due to one of the characteristic symptoms, impairment of short-term memory. The neurotoxin in the mussels was identified as domoic acid (Wright et al. 1989). and its source was traced to the pennate diatom Nitzschia pungens f. multiseries (Bates et al. 1989). Hasle (1993) has recently transferred many of the Nitzschia species, including $N$. pungens, that were previously in the section Pseudonitzschia to the genus Pseudonitzschia; we have adopted this new nomenclature. The domoic-acid-producing diatom has also been isolated from coastal waters of Texas (Fryxell et al. 1990, Dickey et al. 1992), Massachusetts and Rhode Island, USA. Domoic acid has also appeared on the west coast of the United States: the implicated organism in California is the pennate diatom $P$. australis (Buck et al. 1992, Fritz et al. 1992, Garrison et al. 1992), but the causative organism in Oregon and Washington remains uncertain (Wood \& Shapiro 1993). These events have considerably broadened worldwide concern about $p_{\text {seudonitzschia spp. and }}$ domoic acid intoxication.

A complicating factor for programs that monitor for toxic phytoplankton has been the occurrence of Pseudonitzschia pungens blooms without the accompanying domoic acid (Smith et al. 1990). This is a consequence of the fact that $P$. pungens occurs in 2 forms, one that produces domoic acid and is therefore toxic 
(f. multiseries) and the other that is nontoxic (f. pungens). The 2 forms, moreover, are indistinguishable by optical microscope observations and can only be distinguished after the acid-cleaned silica frustules are examined with an electron microscope $;$ f. pungens has 1 to 2 rows of large intercostal poroids rather than the 3 or more rows of smaller poroids found in f. multiseries (Hasle 1965). The existence of the 2 forms can pose problems because of the possibility of false positive indications of a toxic event if the nontoxic f. pungens is dominant (Smith et al. 1990). It is evident that an alternative method for discriminating between the toxic and nontoxic forms of $P$. pungens would be an advantage over the time-consuming and inconvenient method of scanning electron microscopy. Development of an immunofluorescence assay may prove useful to distinguish between the 2 forms.

Immunochemical techniques are increasingly being used to detect and identify marine phytoplankton. In one approach, the indirect immunofluorescence assay, cells are first incubated with a primary antiserum, and then with a fluorescently tagged secondary antiserum directed against the primary antibody, thus rendering the target cells visible with a fluorescence microscope (Campbell et al. 1988). The primary antibodies are obtained by immunizing rabbits with whole phytoplankton cells, and are thus directed against cell surface antigens. This approach was used to identify ultraplanktonic marine coccoid cyanobacteria (Campbell et al. 1983, Campbell \& Carpenter 1987, Campbell 1988), as well as other phytoplankton which are difficult to identify because of their small size and/or lack of characteristic morphological features (Fliermans \& Schmidt 1977. Anderson et al. 1988, Shapiro et al. 1989a, b). Taxonomic relationships among marine phytoplankton have been studied by Campbell \& Carpenter (1987), Hiroishi et al. (1988), Shapiro et al. (1989a) and Uchida et al. (1989), using immunochemical approaches. Polyclonal (Anderson et al. 1988, Vrieling et al. 1993a, b) and monoclonal (Hiroishi et al. 1988, Uchida et al. 1989, Nagasaki et al. 1991, Sako et al. 1992) antibodies have recently been used to detect nuisance and toxic marine phytoplankton cells. Here we report the results of a fluorescein isothiocyanate (FITC) indirect immunofluorescence assay using polyclonal antibodies able to discriminate between the toxic and nontoxic forms of Pseudonitzschia pungens.

\section{MATERIALS AND METHODS}

Immunization cultures. Nonaxenic Pseudonitzschia pungens f. multiseries (clone POM; Seguel 1991) and P. pungens f. pungens (clone BRUD $\mathrm{B}_{i}$ isolated from the Brudenell River, PEI, August 1989) used for immu- nization were grown in $\mathrm{f} / 2$ medium (Guillard \& Ryther 1962) at $18^{\circ} \mathrm{C}$ and at a photon flux density of about $100 \mu \mathrm{E} \mathrm{m}^{-2} \mathrm{~s}^{-1}$ provided by Cool-White fluorescent bulbs (12:12 h light: dark cycle). Cells were harvested by centrifugation at the end of the exponential growth phase (Day 7), and were thus not yet toxic (Bates et al. 1991) as verified by the fluorenylmethoxycarbonyl (FMOC) fluorescence derivatization technique (Pocklington et al. 1990). The pelleted cells were preserved in $0.6 \%(\mathrm{v} / \mathrm{v}$, final concentration) paraformaldehyde prepared in seawater, divided into 5 duplicate $1.0 \mathrm{ml}$ aliquots in microcentrifuge tubes, each containing $5.7 \times 10^{6}$ cells of $\mathrm{f}$. multiseries or $7.5 \times 10^{6}$ cells of $\mathrm{f}$. pungens, and stored at $4{ }^{\circ} \mathrm{C}$ until used for immunization. The identity of the cells was confirmed by scanning electron microscopy (Bates et al. 1989).

Test cultures. The phytoplankton used for the immunological tests, and their origins, are given in Tables 1 to 4 . Test cultures were generally harvested during the late-exponential to early-stationary phase, and preserved in 2 or $5 \%(\mathrm{v} / \mathrm{v}$, final concentration) paraformaldehyde-glutaraldehyde. This was a $1: 1$ solution of $1 \%$ paraformaldehyde $(10 \mathrm{~g}$ solid paraformaldehyde per litre distilled water) in $25 \%$ (fullstrength stock solution) glutaraldehyde. In addition, Pseudonitzschia pungens cells were tested either fresh, frozen or preserved, as indicated, to determine the best fixation procedure to use.

Immunization of rabbits. Rabbits were immunized to produce separate polyclonal antibodies against cell surface antigens of the 2 forms of Pseudonitzschia pungens at East Acres Biologicals (Southbridge, MA). Cells were washed with phosphate-buffered saline (PBS) to remove the preservative, mixed with Freund's complete adjuvant, and a $0.5 \mathrm{ml}$ mixture was then subcutaneously injected into New Zealand White rabbits (initially, 2 for $\mathrm{f}$. multiseries and 2 for $\mathrm{f}$. pungens). Subcutaneous primary immunization was chosen in preference to intravenous injections to increase the residence time of the cells for antibody production, and because of the concern that whole $P$. pungens cells (about $70 \mu \mathrm{m}$ long $\times 5 \mu \mathrm{m}$ wide) could become clogged in the rabbit's circulatory system. No attempt was made to break apart the chains, which were less than 4 cells long. A schedule of 5 boosts, with $0.5 \mathrm{ml}$ of cells in Freund's incomplete adjuvant, was carried out at $3 \mathrm{wk}$ intervals. When an acceptable titre was achieved, production bleeds were obtained weekly via the marginal ear vein. The blood was allowed to clot for $1 \mathrm{~h}$ in a water bath, and then was centrifuged twice to remove red blood cells, yielding 20 to $25 \mathrm{ml}$ of serum per bleed. Each delivery of serum was tested, divided into $1.0 \mathrm{ml}$ aliquots and stored at $-20^{\circ} \mathrm{C}$. The rabbits were then boosted monthly with the same cell concentration as was used for the immunization. Different rabbits were 
Table 1. Clones of Pseudonitzschia pungens f. multiseries. Summary of results obtained by indirect immunofluorescence assay using antisera raised against $P$. pungens $f$. multiseries and $P$. pungens f. pungens. Immunological cross reactivity is scaled from very strong $(+++)$ to none (-). Clone prefixes are TV: collection of T. A. Villareal; F: collection of G. A. Fryxell; CCMP: Guillard-Provasoli Culture Collection of Marine Phytoplankton

\begin{tabular}{|c|c|c|c|c|c|}
\hline \multirow[t]{2}{*}{ Clone } & \multirow[t]{2}{*}{ Date isolated } & \multirow[t]{2}{*}{ Location isolated } & \multirow[t]{2}{*}{ Isolated by } & \multicolumn{2}{|c|}{ Antiserum } \\
\hline & & & & f. multiseries & f. pungens \\
\hline NPARL & 14 Mar 1988 & Cardigan Bay, PEI, Canada & S. Bates & ++ & - \\
\hline BRUD A & 10 Aug 1989 & Brudenell River, PEI, Canada & C. Léger & +++ & - \\
\hline TKA-2 & 25 May 1989 & Galveston, TX, USA & T. Ashworth & + & - \\
\hline POM & Nov 1989 & Pomquet Harbour, NS, Canada & M. Seguel & +++ & - \\
\hline KP-59 & 18 Oct 1991 & New London Bay, PEI, Canada & K. Pauley & +++ & - \\
\hline TV-2 & $2 \operatorname{Mar} 1992$ & Massachusetts Bay, MA, USA & T Villareal & + & - \\
\hline TV-7 & 2 Mar 1992 & Massachusetts Bay, MA, USA & T. Villareal & +++ & - \\
\hline TV -12 & 2 Mar 1992 & Massachusetts Bay, MA, USA & T. Villareal & +++ & - \\
\hline TV -13 & 2 Mar 1992 & Massachusetts Bay, MA, USA & T. Villareal & ++ & - \\
\hline TV -14 & 2 Маг 1992 & Massachusetts Bay, MA, USA & T. Villareal & +++ & - \\
\hline TV -17 & 2 Mar 1992 & Massachusetts Bay, MA, USA & T. Villareal & +++ & - \\
\hline TV -18 & 2 Маг 1992 & Massachusetts Bay, MA, USA & T. Villareal & ++ & - \\
\hline B991K & Sep 1991 & Narragansett Bay, RI, USA & P. Hargraves & +++ & - \\
\hline $892 \mathrm{G}$ & Aug 1992 & Narragansett Bay, RI, USA & P. Hargraves & +++ & - \\
\hline$F 279 m^{a}$ & 13 Aug 1989 & Galveston, TX, USA & G. Fryxell & +++ & - \\
\hline $\mathrm{F} 288 \mathrm{~m}^{\mathrm{b}}$ & 14 Aug 1989 & Galveston, TX, USA & G. Fryxell & ++ & - \\
\hline F296 & 10 Mar 1990 & Galveston, TX, USA & G. Fryxell & +++ & - \\
\hline F302 & 11 Mar 1990 & Galveston, TX, USA & G. Fryxell & +++ & - \\
\hline F307 & 8 Jun 1990 & Galveston, TX, USA & G. Fryxell & +++ & - \\
\hline F340 & 29 Mar 1991 & Galveston, TX, USA & G. Fryxell & ++ & - \\
\hline F433 & 27 May 1992 & Galveston, TX, USA & G. Fryxell & +++ & - \\
\hline F445 & 27 May 1992 & Galveston, TX, USA & G. Fryxell & +++ & - \\
\hline F415d & 17 Jun 1992 & Galveston, TX, USA & G. Fryxell & ++ & - \\
\hline F435 & 27 May 1992 & Galveston, TX, USA & G. Fryxell & +++ & - \\
\hline CCMP562 & 10 Mar 1990 & Galveston, TX, USA & G. Fryxell & +++ & - \\
\hline CCMP565 & 25 May 1989 & Galveston, TX, USA & T. Ashworth & ++ & - \\
\hline CCMP566 & 18 Jul 1989 & Galveston, TX, USA & M. Davis & ++ & - \\
\hline CCMP567 & 11 Mar 1990 & Galveston, TX, USA & G. Fryxell & +++ & - \\
\hline CCMP569 & 11 Mar 1990 & Galveston, TX, USA & G. Fryxell & +++ & - \\
\hline CCMP570 & 11 Mar 1990 & Galveston, TX, USA & G. Fryxell & +++ & - \\
\hline CCMP57 1 & 18 Jul 1989 & Galveston, TX, USA & M. Davis & +++ & - \\
\hline
\end{tabular}

immunized with f. multiseries on 2 occasions (July 1991 and February 1992).

Immunofluorescence protocol. The indirect immunofluorescence protocol used (Fig. 1) was modified from that of Anderson et al. (1988). All solutions were filter sterilized $(0.22 \mu \mathrm{m}$ Millipore filter). Two incubation approaches were evaluated using Pseudonitzschia pungens as the test organism: cells were incubated with the test serum on either $1.0 \mu \mathrm{m}$ Nuclepore polycarbonate membrane filters (Anderson et al. 1988), or in $1.5 \mathrm{ml}$ microcentrifuge tubes. Both approaches were successful, but the latter was used for the majority of the tests presented here. For the centrifugation approach, 1.5 to $3.0 \mathrm{ml}$ of culture was first rinsed 3 times [Eppendorf Model 5415 microcentrifuge; 2 min at $8000 \mathrm{rpm}(5220 \times g)]$ with PBS $(0.02 \mathrm{M}$ phosphate; $0.15 \mathrm{M} \mathrm{NaCl} ; \mathrm{pH} 7.45$ ) to remove the seawater or preservative. Cells were then incubated for $40 \mathrm{~min}$ at room temperature with $1.0 \mathrm{ml}$ of a blocking agent, $3 \%$ normal goat serum (G-9023, Sigma) in PBS. Cells were centrifuged 3 times in $1.0 \mathrm{ml}$ of PBS as a rinse. This was followed by a $40 \mathrm{~min}$ incubation in the primary test antiserum, diluted to 1:10 with PBS; higher dilutions were used in other tests. Parallel samples were incubated for 40 min with normal rabbit serum (from the preimmunization rabbit or R-9133 from Sigma) in place of the antiserum, as a control. After rinsing 3 times with $1.0 \mathrm{ml}$ of PBS, the cells were incubated for $20 \mathrm{~min}$ with $1.0 \mathrm{ml}$ of FITC-conjugated goat anti-rabbit antiserum (F-0382, Sigma), diluted to 1:800 with PBS, as the secondary antibody. We later showed that the above incubation times could be shortened to 15 min with the blocking agent and primary antiserum and $10 \mathrm{~min}$ with the secondary antiserum, but times should be tested for each new batch of serum. After a final triplicate rinse and resuspension in $0.5 \mathrm{ml}$ of PBS, a drop of sample was placed on a microscope slide and examined at $250 \times$ or $400 \times$ with a Leitz Orthoplan fluorescence 
Table 2. Clones of Pseudonitzschia pungens f pungens. Summary of results obtained by indirect immunofluorescence assay using antisera raised against $P$. pungens $f$. multiseries and $P$. pungens f. pungens. Immunological cross reactivity is scaled from very strong $(+++)$ to none $(-)$

\begin{tabular}{|c|c|c|c|c|c|}
\hline \multirow[t]{2}{*}{ Clone } & \multirow[t]{2}{*}{ Date isolated } & \multirow[t]{2}{*}{ Location isolated } & \multirow[t]{2}{*}{ Isolated by } & \multicolumn{2}{|c|}{ Antiserum } \\
\hline & & & & f. multiseries & f. pungens \\
\hline BRUD B & 10 Aug 1989 & Brudenell River, PEI, Canada & C. Léger & - & +++ \\
\hline BRUD C & 24 Aug 1989 & Brudenell River, PEI, Canada & C. Léger & - & +++ \\
\hline CARA & 17 Nov 1989 & Cardigan Bay, PEI, Canada & C. Léger & - & +++ \\
\hline NP90-07 & 31 Jul 1990 & Cardigan Bay, PEI, Canada & C. Léger & - & ++ \\
\hline NP90-08 & 31 Jul 1990 & Cardigan Bay, PEI, Canada & C. Léger & - & ++ \\
\hline KP-60 & 18 Oct 1991 & New London Bay, PEI, Canada & K. Pauley & - & ++ \\
\hline TV-16 & 2 Mar 1992 & Massachusetts Bay, MA, USA & T. Villareal & - & ++ \\
\hline B991I & Sep 1991 & Narragansett Bay, RI, USA & P. Hargraves & & - \\
\hline F378 & 21 Sep 1991 & Galveston, TX, USA & G. Fryxell & - & + \\
\hline F384 & 1 Nov 1991 & Newport, RI, USA & G. Fryxell & - & ++ \\
\hline F386 & 1 Nov 1991 & Newport, RI, USA & G. Fryxell & - & ++ \\
\hline F390 & 1 Nov 1991 & Newport, RI, USA & G. Fryxell & - & ++ \\
\hline F391 & 1 Nov 1991 & Newport, RI, USA & G. Fryxell & - & +++ \\
\hline F394 & 1 Nov 1991 & Newport, RI, USA & G. Fryxell & - & ++ \\
\hline $\mathrm{F} 400$ & 1 Nov 1991 & Narragansett, RI, USA & G. Fryxell & - & ++ \\
\hline $\mathrm{F} 402$ & 1 Nov 1991 & Narragansett, RI, USA & G. Fryxell & - & +++ \\
\hline F403 & 1 Nov 1991 & Narragansett, RI, USA & G. Fryxell & - & $t+t$ \\
\hline ORI-8 & 14 Dec 1991 & Ilwaco, WA, USA & M. Villac & - & ++ \\
\hline CCMP572 & 14 Aug 1989 & Galveston, TX, USA & G. Fryxell & ++ & - \\
\hline $\mathrm{CCMP}_{7} 73^{\mathrm{a}}$ & 13 Aug 1989 & Galveston, TX, USA & G. Fryxell & ++ & - \\
\hline
\end{tabular}

Table 3. Phytoplankton species of the genera Pseudonitzschia (other than $P$. pungens) and Nitzschia. Summary of results obtained by indirect immunofluorescence assay using antisera raised against $P$. pungens f. multiseries and $P$. pungens $\mathrm{f}$. pungens. Immunological cross reactivity is scaled from very strong $(+++)$ to none $(-)$

\begin{tabular}{|c|c|c|c|c|c|}
\hline \multirow[t]{2}{*}{ Clone } & \multirow[t]{2}{*}{ Species } & \multirow[t]{2}{*}{ Location isolated } & \multirow[t]{2}{*}{ Isolated by } & \multicolumn{2}{|c|}{ Antiserum } \\
\hline & & & & f. multiseries & f. pungens \\
\hline NP90-05 & Nitzschia sp. & Cardigan Bay, PEI, Canada & C. Léger & - & - \\
\hline CCMP551 & Nitzschia brevirostris & Oyster Pond, MA, USA & R. Guillard & - & - \\
\hline CCMP554 & N. curta & $57^{\circ} 46^{\prime} \mathrm{S}, 31^{\circ} 52^{\prime} \mathrm{W}$ & G. Fryxell & - & - \\
\hline CCMP555 & N. curvilineata & New Haven, CT, USA & J. Lewin & - & - \\
\hline CCMP557 & N. cylindrus & Antarctica & G. Fryxell & - & - \\
\hline CCMP558 & N. frustulum & Prospect, NS, Canada & J. Lewin & - & - \\
\hline CCMP561 & N. punctata & San Diego, CA, USA & J. Lewin & - & - \\
\hline CCMP576 & N. cf constricta & Coral Sea, Australia & S. Jeffrey & - & - \\
\hline CCMP1118 & N. cf. ovalis & Magdalena Bay, Mexico & A. Dodson & - & - \\
\hline CCMP1309 & Pseudonitzschia seriata & Resolute Bay, NWT, Canada & R. Smith & - & - \\
\hline CCMP1437 & P. subcurvata & McMurdo Sound, Antarctica & G. Fryxell & $+a$ & $t^{a}$ \\
\hline CCMP1438 & P. subcurvata & McMurdo Sound, Antarctica & G. Fryxell & - & - \\
\hline CCMP1443 & P. subcurvata & McMurdo Sound, Antarctica & G. Fryxell & - & - \\
\hline CCMP1444 & P. subcurvata & McMurdo Sound, Antarctica & G. Fryxell & + & + \\
\hline $\mathrm{B} 991 \mathrm{H}$ & P. fraudulenta & Narragansett Bay, RI, USA & P. Hargraves & $+^{a}$ & - \\
\hline N1 & P. pseudodelicatissima & Massachusetts Bay, MA, USA & T Villareal & - & - \\
\hline F379 & P. pseudodelicatissima & Galveston, TX, USA & G. Fryxell & $+^{\dot{a}}$ & - \\
\hline F380 & P. pseudodelicatissima & Galveston, TX, USA. & G. Fryxell & $t^{d}$ & - \\
\hline F397 & P. pseudodelicatissima & Newport, RJ, USA & G. Fryxell & $+{ }^{\dot{a}}$ & - \\
\hline P:SID & P. australis & Monterey Bay, CA, USA & D. Douglas & - & - \\
\hline $\mathrm{MB} 27$ & P. australis & Monterey Bay, CA, USA & M. Villac & $+{ }^{a}$ & $t^{a}$ \\
\hline MB1 & P. australis & Monterey Bay, CA, USA & M. Villac & $t^{a}$ & $+{ }^{a}$ \\
\hline MB7d & P. australis & Monterey Bay, CA, USA & M. Villac & $+{ }^{a}$ & $t^{a}$ \\
\hline MB8d & P. australis & Monterey Bay, CA, USA & M. Villac & $+*$ & $+{ }^{a}$ \\
\hline MB33a & P. australis & Monterey Bay, CA, USA & M. Villac & $++^{+}$ & $+{ }^{a}$ \\
\hline ORI-2 & P. australis & Ilwaco, WA, USA & M. Villac & $++^{a}$ & $t^{2}$ \\
\hline ORI-4 & P. australis & Ilwaco, WA, USA & M. Villac & $t^{a}$ & $t^{a}$ \\
\hline
\end{tabular}


Table 4. Phytoplankton species representing major classes. Summary of results obtained by indirect immunofluorescence assay using antisera raised against Pseudonitzschia pungens $\mathrm{f}$. multiseries and $P$. pungens $\mathrm{f}$. pungens. Immunological cross reactivity is scaled from very strong $(+++)$ to none $(-)$. Isolation locations are given in the CCMP Catalogue of Strains, except for Bacillaria paxillifer, which was isolated in 1990 from Galveston, Texas, USA, and Amphora coffaeiformis, which was isolated in 1987 by L. Maranda from Cardigan Bay, PEI, Canada

\begin{tabular}{|lllc|}
\hline Clone & Species & Class & Antiserum \\
& & & f. multiseries \\
fCMngens \\
CCMP169 & Chaetoceros concavicornis & Bacillariophyceae & - \\
CCMP543 & Fragilaria pinnata & Bacillariophyceae & - \\
CCMP630 & Navicula pelliculosa & Bacillariophyceae & - \\
CCMP974 & Phaeodactylum tricornutum & Bacillariophyceae & - \\
CCMP1049 & Thalassionema nitzschoides & Bacillariophyceae & - \\
CCMP1442 & Thalassiosira weissflogii & Bacillariophyceae & - \\
CCMP1439 & Thalassiosira gravida & Bacillariophyceae & - \\
CCMP1332 & Skagilariopsis ritscheri & Bacillariophyceae & - \\
JW-1 & Bacillaria paxillifer & Bacillariophyceae & - \\
BPT-11 & Amphora coffaeiformis & Bacillariophyceae & - \\
CCMP364 & Dunaliella tertiolecta & Bacillariophyceae & - \\
CCMP452 & Heterosigma akashiwo & Chlorophyceae & - \\
CCMP462 & Isochrysis galbana & Raphidophyceae & - \\
CCMP674 & Porphyridium aeruginium & Prymnophyceae & - \\
CCMP739 & Rhodomonas lens & Rhodophyceae & - \\
CCMP833 & Synechoccus sp. & Cryptophyceae & - \\
CCMP878 & Tetraselmis apiculata & Cyanophyceae & - \\
aSlight labelling & & Prasinophyceae & - \\
\end{tabular}

microscope (Leitz 2 filter block for excitation light; Block I for transmitted light) or a Zeiss IM35 inverted epifluorescence microscope (Anderson et al. 1988). All tests were read 'blind', i.e. the person reading and scoring the tests did not know the identity of the test material. Each sample was rated for the visual intensity of fluorescence from excellent $(+++)$ to weak $(+)$, with a $(-)$ indicating no antigenic reaction relative to the control incubated with preimmunization rabbit serum.

\section{RESULTS}

\section{Titre tests}

Usable antisera were obtained $116 \mathrm{~d}$ after the primary injection for the first set of rabbits immunized in July 1991 with Pseudonitzschia pungens f. multiseries or $P$. pungens $\mathrm{f}$. pungens, and by Day 52 for the second set immunized in February 1992 with $P$. pungens f. multiseries. For f. multiseries, an antiserum dilution of $1: 1000$ was the lowest concentration that produced visible labelling around the perimeter of the cell. The f. pungens antiserum had a slightly lower titre, with labelling at a dilution of 1:500. A working dilution of $1: 10$ to $1: 20$ was generally used for the tests, as no cross reactivity was observed between the 2 forms, even at these high antibody concentrations. Successful labelling was characterized by a bright green fluorescent band around the outer edge of the cell (Fig. 2), indicating that surface antigens were indeed labelled. We observed no background fluorescence in the cells, other than the occasional yellow-red-orange autofluorescence due to chlorophyll a.

\section{Preservation techniques}

Several different preservation techniques were evaluated to determine which gave acceptable immunofluorescent results. Cells preserved with solutions of $2 \%$ ( $\mathrm{v} / \mathrm{v}$, final concentration) glutaraldehyde-paraformaldehyde, paraformaldehyde, or boratebuffered formalin gave the strongest fluorescence labelling (Table 5). Pseudonitzschia pungens cells frozen at $-60^{\circ} \mathrm{C}$ with no preservative also gave a bright fluorescence and maintained their shape even after thawing. The labelling intensity of the preserved or frozen cells was about equal to that of 'live' cells. Cells retained their FITC fluorescence for at least 6 mo after being labelled, if kept refrigerated at $4{ }^{\circ} \mathrm{C}$.

\section{Effects of culture age}

The time since inoculation into batch culture appeared to have a small, but noticeable, influence on 


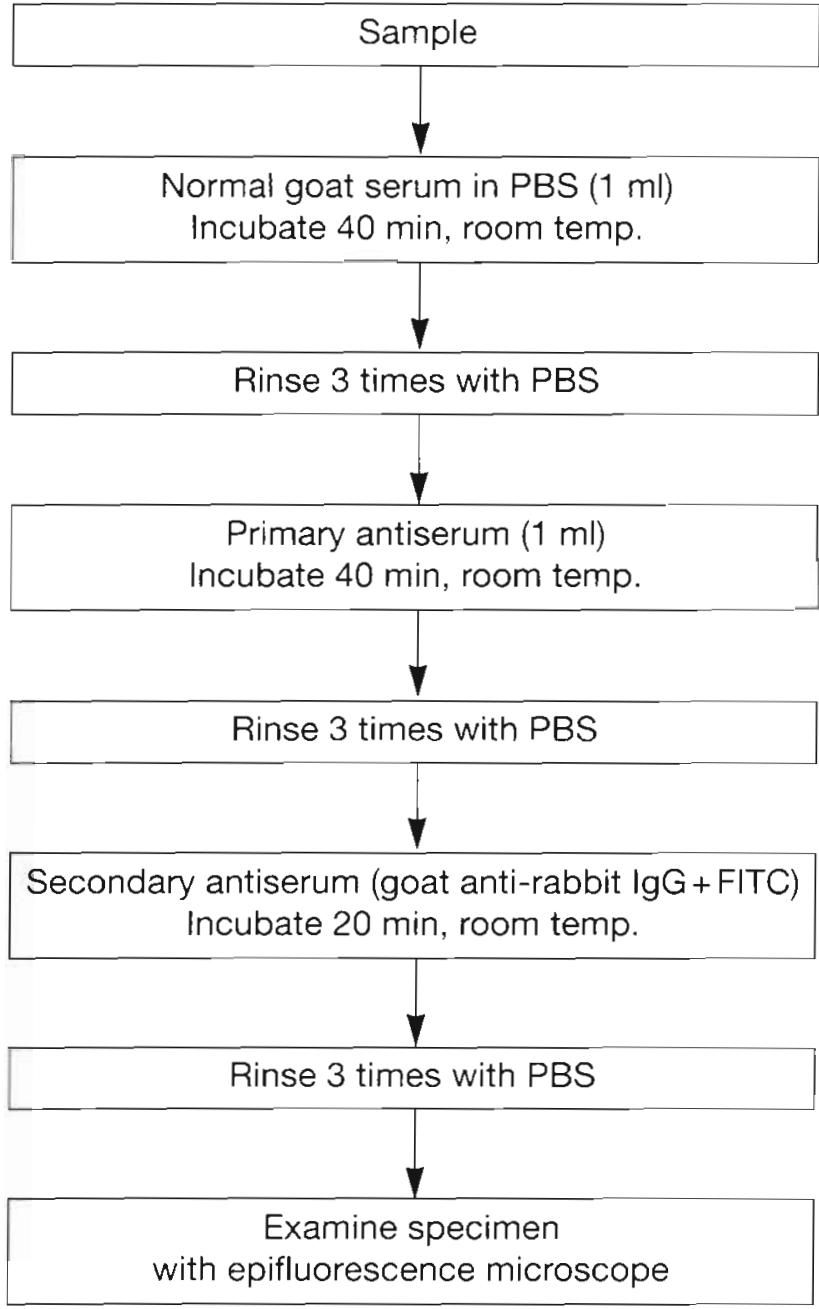

Fig. 1. Immunofluorescence protocol (Anderson et al. 1988), applicable to either the filtration or the centrifugation approach. Incubation times can be shortened (see text)

the strength of the immunological reaction for both f. multiseries and f. pungens (Table 6). Cultures in the mid- to late-stationary phase appeared to have a greater affinity for the antisera than exponential to early-stationary phase cultures.

\section{Effects of incubation time}

Decreasing the incubation time with the sera by $75 \%$ (i.e. 10 min each for the blocking agent and primary antiserum, and $5 \mathrm{~min}$ for the secondary antiserum) still resulted in good labelling ('++') of the cells. However, a visibly stronger labelling ('+++') was observed with. the longer incubation times normally used (i.e. 40 min each for the blocking agent and primary antiserum, and 20 min with the secondary antiserum).
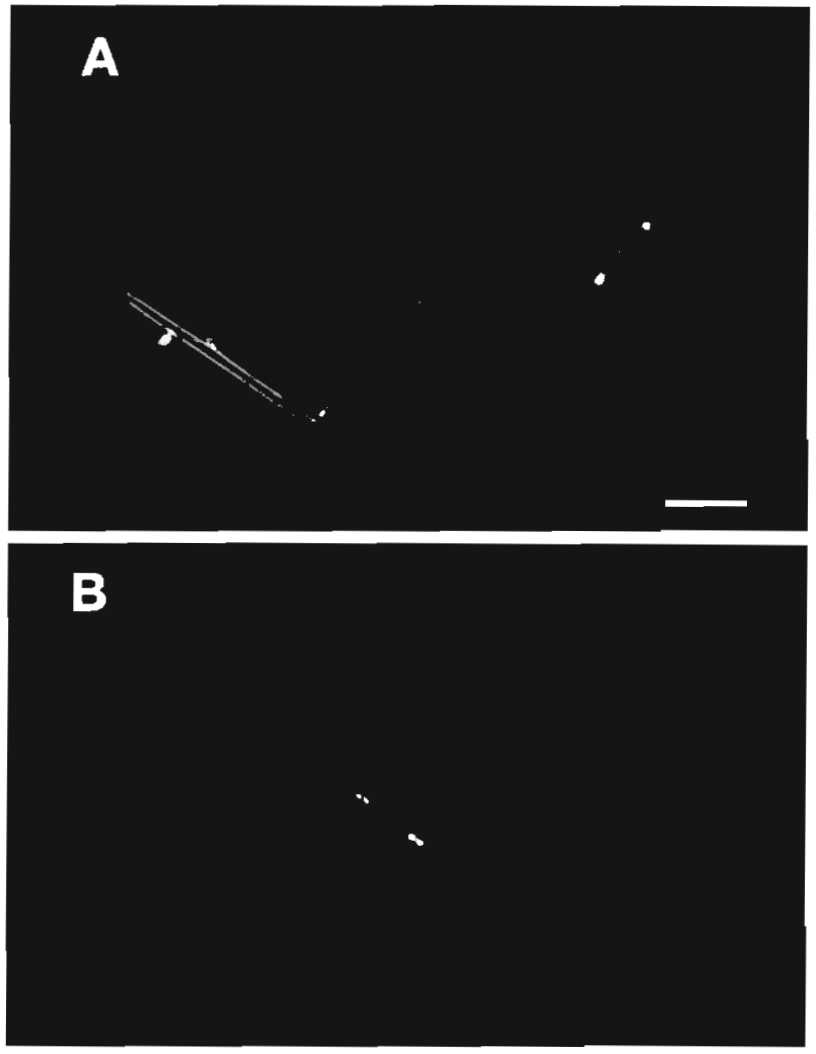

Fig. 2. Pseudonitzschia pungens. Epifluorescence photomicrographs of $P$. pungens f, pungens (Clone F391). (A) Cells incubated with the $\mathrm{f}$. pungens antibody and the FITCconjugated goat anti-rabbit antibody. The label is confined to the outer cell surface as shown by the bright band around the parameter of the cells; labelling for $P$. pungens f. multiseries incubated with the $f$. multiseries antiserum is identical in appearance. Most chains break up into single cells during the centrifugation and incubation steps. (B) Control cells incubated with normal rabbit serum in place of the $\mathrm{f}$. pungens antiserum, indicating the absence of labelling. The paired spots are autofluorescence of chlorophyll $a$ within the chloroplasts, normally seen as yellow-red-orange rather than as the green fluorescence of FITC. Scale bar $=20 \mu \mathrm{m}$

\section{Cross reactivity tests}

Over 150 phytoplankton cultures were used to test for specificity and cross reactivity, i.e. reactions of the antiserum against antigen(s) not present in the immunization preparation (Campbell et al. 1988). Separate antibodies were produced against the cell surface of the 2 forms of Pseudonitzschia pungens, and each of the resulting antisera were specific to f. multiseries (Table 1) or to $\mathrm{f}$. pungens (Table 2), with no cross reactivity with the other form (Tables $1 \& 2$ ). There was no evident difference in labelling between axenic and nonaxenic test cultures. Positive antibody labelling was found not only with clones of $P$. pungens isolated from eastern PEI, the origin of the cells used 
Table 5. Comparison of various preservation techniques, including freezing, on the immunofluorescent reaction between $\mathrm{f}$. pungens antiserum (diluted to $1: 20$ ) and Pseudonitzschia pungens f. pungens (Clone BRUD B); samples remained in the fixative or were frozen for $11 \mathrm{~d}$ prior to testing. Immunological reactivity is scaled from very strong $(+++)$ to good $(++)$

\begin{tabular}{|lcc|}
\hline Preservation technique & $\begin{array}{c}\text { Strength } \\
(\%)\end{array}$ & $\begin{array}{c}\text { Immunofluorescent } \\
\text { reaction }\end{array}$ \\
\hline Glutaraldehyde-paraformaldehyde & 2.0 & +++ \\
Paraformaldehyde & 2.0 & +++ \\
Borate-buffered formaldehyde & 2.0 & +++ \\
Lugol's iodine & 4.0 & ++ \\
Glutaraldehyde & 0.5 & ++ \\
Formalin-acetic acid & 2.0 & ++ \\
Frozen at $-60^{\circ} \mathrm{C}$ & & +++ \\
Frozen at $-20^{\circ} \mathrm{C}$ & & ++ \\
\hline
\end{tabular}

Table 6. Pseudonitzschia pungens. Effect of culture age on the immunological response of antisera raised against $P$. pungens $\mathrm{f}$. multiseries and $P$ pungens $\mathrm{f}$. pungens. Samples had been kept frozen at $-20^{\circ} \mathrm{C}$ for 6 mo prior to the assay. Immunological reactivity is scaled from very strong $(+++)$ to weak but observable $(+)$

\begin{tabular}{|ccc|}
$\begin{array}{c}\text { Culture age } \\
\text { (d) }\end{array}$ & $\begin{array}{c}\text { f. multiseries clone } \\
\text { (BRUD A) }\end{array}$ & $\begin{array}{c}\text { f. pungens clone } \\
\text { (CARA) }\end{array}$ \\
\hline 4 & + & ++ \\
9 & + & ++ \\
16 & ++ & +++ \\
24 & ++ & +++ \\
32 & ++ & +++ \\
\hline
\end{tabular}

for the immunizations, but also with clones from northern PEI, Nova Scotia, Massachusetts, Rhode Island, Texas, and Washington (Tables 1 \& 2). There was a slight difference in labelling intensity with clones originating from these different North American locations and at different times of the year from these locations. However, since there were also small differences in fluorescence intensity even between clones isolated from the same location, this is not considered to be a problem. The positive reactions wore unquestionable.

In 2 cases (Clones CCMP572 and CCMP573; Table 2), the antibody assays indicated that the diatom was Pseudonitzschia pungens f. multiseries, but the expected identification given was f. pungens. When the same clones (designated as F279m and F288m in Table 1) were received from Dr G. A. Fryxell's collection (Texas A\&M University, College Station, TX), a note indicated that they were identified as $\mathrm{f}$. pungens when originally isolated, but that recent observation by scanning electron microscopy had, in fact, identified them as f. multiseries. Our immunofluorescence results had indeed also identified these clones as f. multiseries, not f. pungens.
Twenty-seven other pennate diatom clones from the Pseudonitzschia and Nitzschia genera were examined for cross reactivity (Table 3 ). No cross reactions were found, with the exception of 4 species. $P(=N$ ) pseudodelicatissima (Clones F379 and F380) from Galveston, Texas, and P. pseudodelicatissima (Clone F397) from Newport, Rhode Island, showed a slight positive response with the f. multiseries antiserum. However, $P$. pseudodelicatissima (Clone N1) from Massachusetts Bay showed a negative response with antisera from both f. multiseries and f, pungens. Other samples of $P$. pseudodelicatissima must be tested to resolve this discrepancy.P. australis, believed to be responsible for the domoic acid incident in Monterey Bay, California (Fritz et al. 1992), also gave mixed results; either a negative reaction (for Clone $\mathrm{P}$ :SID) with both $\mathrm{f}$. multiseries and f. pungens antisera or a slight positive reaction with both antisera (clones from Monterey Bay and Ilwacol. The slight positive reaction was not great enough to cause concern about misidentification, but it does pose some interesting questions about the evolutionary relationship between the domoic acid producers $P$. pungens $f$. multiseries and $P$. australis. $P$. fraudulenta (Clone $\mathrm{B} 991 \mathrm{H}$ ) also gave a slight positive reaction with the f. multiseries antiserum. Finally, $P$. subcurvata (Clones CCMP1437 and CCMP1444) gave a. slight positive response for both antisera, following triplicate test.s. Clones CCMP1438 and CCMP1443 of this same species also gave a slight labelling, but it appeared to be confined to the interior of the cell rather than to the cell surface, and was therefore scored as a negative.

Ten other representatives of the class Bacillariophyceae, including Fragilariopsis ritscheriand Bacillaria paxillifer, did not cross react with the antiserum from either f. multiseries or f. pungens (Table 4). However, the domoic-acid-producing Amphora coffaeiformis (Clone BPT-11, Maranda et al. 1990) labelled slightly with both antisera. Nevertheless, representative species from 7 other major classes of phytoplankton did not cross react (Table 4), nor did numerous other species, including the dinoflagellates Dinophysis spp. and Prorocentrum spp: and the diatoms Skeletonema costatum, Chaetoceros spp., and Rhizosolenia spp., in natural samples collected in Cardigan Bay and New London Bay, PEI, in October and November 1992 (S. C. S. Smith unpubl.). These same samples, however, did contain Pseudonitzschia sp. cells that reacted strongly with the f. multiseries and the f. pungens antisera when tested separately, clearly indicating the presence of both forms in a field situation. 


\section{DISCUSSION}

The indirect immunofluorescence assay, using polyclonal antisera, successfully distinguished the domoicacid-producing Pseudonitzschia pungens f. multiseries from the nontoxic $P$. pungens $\mathrm{f}$. pungens, with no cross reactions between the 2 forms. Such fine-scale immunospecificity has not been demonstrated previously for marine phytoplankton, which have generally shown genus-specific or species-specific reactions (Anderson et al. 1988, Campbell et al. 1988, Shapiro et al. 1989 a, b, Vrieling et al. 1993b). Our results indicate that unique and as yet unidentified epitopes exist on the cell surface of each form, raising some interesting phylogenetic questions. This provides additional evidence, beyond the differences in morphology and the capability to produce domoic acid, that there is genetic separation between these 2 forms (G. A. Fryxell pers. comm.).

Antibody reactions were found not only with clones of Pseudonitzschia pungens isolated from eastern PEI (the origin of the cells used for the immunizations), but also with $P$. pungens from northern PEI, Nova Scotia, Massachusetts, Rhode Island, Texas, and Washington. These results indicate that there is genetic continuity of cell surface antigens on $P$. pungens clones isolated from diverse geographical areas. Similar immunological results were described by Shapiro et al. (1989b) for other cosmopolitan species. On the other hand, slight clonal variations in labelling intensity may be expected (Wood \& Leatham 1992). The only exception to the labelling pattern was Clone B991I, identified as $P$. pungens $f$. pungens, but which did not react with either of the antisera (Table 2). This clone will be examined in more detail.

The potential utility of the assay was demonstrated when repeated tests indicated Clones CCMP572 and CCMP573 to be f. multiseries (Table 2), although they were originally identified as f. pungens in the CCMP Catalogue of Strains. Updated information received from Dr G. A. Fryxell showed that these clones (also designated as $1279 \mathrm{~m}$ and $\mathrm{F} 288 \mathrm{~m}$, respectively, in Table 1) were initially identified as f. pungens, but were in fact now f. multiseries (probably due to contamination). In another instance, our immunofluorescence assay correctly showed that the identifications of 2 P. pungens clones from New London Bay, PEI, had inadvertently been reversed. Such assays may therefore also serve as a check on the taxonomic identifications of phytoplankton, analogously to the way in which RNA or DNA sequences can be used to separate Alexandrium species (Scholin \& Anderson 1993). Immunofluorescence assays may be especially useful for diatoms, whose taxonomy is based primarily on frustule morphology. Frustule morphology, however, can change with environmental (Schmid 1979, Mizuno 1987) and culture conditions. For example, cells in some of our $P$. pungens cultures have become so deformed (cf. Takano \& Kikuchi 1985, Subba Rao \& Wohlgeschaffen. 1990) and short (because sexual reproduction has not taken place) that they no longer fit the species definition for $P$. pungens (Hasle 1965). Nevertheless, all of our $\mathrm{f}$. multiseries and $\mathrm{f}$. pungens clones reacted with the appropriate antiserum, regardless of cell size or the presence of deformities.

As promising as this immunoassay is for distinguishing the 2 forms of Pseudonitzschia pungens, no assay is completely infallible. Slight labelling was found with 3 other species of domoic-acid-producing pennate diatoms: P. pseudodelicatissima (Martin et al. 1990), P. australis (Buck et al. 1992, Fritz et al. 1992, Garrison et al. 1992), and Amphora coffaeiformis (Maranda et al. 1990). Again, it would be interesting to study the phylogeny of these diatoms, for example with RNA probes (cf. Scholin \& Anderson 1993). P. subcurvata (Clones CCMP1437 and CCMP1444) also labelled slightly, but at least 1 of these clones (CCMP1437 = MC-2) did not produce domoic acid at a detection limit of $3.28 \mathrm{fg} \mathrm{cell}^{-1}$ (Fryxell et al. 1991). It is unlikely that $P$. subcurvata could be confused with $P$. pungens in North American waters because of its mainly Antarctic distribution (Fryxell et al. 1991)

The working titre found in this study (10 to 200) was lower than that reported for other phytoplankton: 3200 for a chrysophyte; 12800 for a prymnesiophyte (Campbell et al. 1988); and 12800 for the 'brown tide' chrysophyte Aureococcus anophagefferens (Anderson et al. 1988). Nevertheless, the antibodies were relatively easily, rapidly and consistently produced by at least 4 rabbits used thus far. It is interesting to note that there were no cross reactions between the 2 forms, even at the high antibody concentration of $1: 10$ used for the majority of the tests reported here. A working dilution of 1.50 is recommended for field and laboratory tests, as this concentration adequately labels the cells and conserves antiserum. It is also likely that the slight cross reactions seen with Pseudonitzschia pseudodelicatissima, $P$. fraudulenta, and $P$. australis would not be visible at the 1:50 dilution.

Labelling was good to excellent with the 6 preservatives tested (Table 5), and each preservative also maintained structural integrity of the cells. We did not observe the nonspecific staining seen by Campbell et al. (1988) and Shapiro et al. (1989b) for glutaraldehydepreserved cells. Cells frozen at -20 and $-60^{\circ} \mathrm{C}$ also gave good to excellent labelling, even after 6 mo (Table 6). The fluorescence yield did not appreciably increase by adding glycerol to the microscope slide (cf. Anderson et al. 1988), nor by raising the $\mathrm{pH}$ of the mounting medium (cf. Goldman 1968, Ward 1982. 
Campbell et al. 1983). The capability of the immunofluorescence assay described here to discriminate between the toxic and nontoxic forms of Pseudonitzschia pungens in glutaraldehyde-paraformaldehydepreserved field samples was also demonstrated.

The slightly better labelling of Pseudonitzschia pungens cells during the stationary phase (Table 6) suggests that the quantity and/or quality of epitopes on the cell surface changes over time. Although this may be expected, it is difficult to explain the apparently stronger reactions with stationary-phase than with exponential-phase cells, because the cells used for immunization were in fact harvested during the lateexponential phase (Day 7). It is interesting to note the relationship between the strength of the labelling and the production of domoic acid, both of which are most evident during the stationary phase (Bates et al. 1991).

Incubation times were taken from Anderson et al. (1988) and thus were not necessarily optimized. They could be considerably reduced from the 40 min used, as evidenced by good labelling even after a $10 \mathrm{~min}$ incubation period with the primary antiserum and a $5 \mathrm{~min}$ period with the secondary antiserum. A $15 \mathrm{~min}$ period for the blocking agent and primary antiserum is probably sufficient, but these times should be optimized for each new bleed and rabbit. The assay has also not yet been optimized to increase the number of laboratory or field samples processed at one time. Up to 18 incubations could easily be carried out simultaneously with the centrifugation approach, which was convenient for laboratory cultures requiring only 1.5 to $3.0 \mathrm{ml}$ of sample because of their high biomass. However, if larger volume, low biomass 'whole water' field samples are to be processed, the cells must first be concentrated. This is most conveniently done by filtration (Anderson et al. 1988), as was also demonstrated in our study, provided that the filtration apparatus has a sufficient capacity for filters. Sample throughput could be increased if cells could be made to stick onto histological microscope slides (e.g. Ward \& Perry 1980), which would then be incubated and rinsed in batches

The number of samples processed could be doubled by simultaneously using 2 secondary antibodies conjugated to fluorochromes that emit at different wavelengths. For example, the currently used greenfluorescing fluorescein isothiocyanate (FITC) could be used to visualize f. pungens, and the red-fluorescing tetramethylrhodamine isothiocyanate (TRITC) could be used for f. multiseries. In this way, only 1 sample need be incubated to distinguish the 2 forms of Pseudonitzschia pungens. However, for the $2 \mathrm{sec}-$ ondary antibodies to recognize the primary antibodies, the latter must be developed in 2 different animal species (e.g. f. pungens in rabbits and f. multiseries in goats), and the animal species in which 1 of the secondary antibodies originates must also be different. Alternatively, a direct immunofluorescence assay could be used in which the 2 fluorochromes aro conjugated directly to the respective primary antibodies produced in the same animal species

It was important for the development of this assay to be able to visualize which cells were labelled, using a fluorescence microscope. Aside from being able to look for cross reactions, this approach also has the advantage that cell counts of each form of Pseudonitzschia pungens can be made. In future developments of the technique, the fluorescence intensity could be quantified by conventional fluorometers or by flow cytometry (Cucci \& Robins 1988, Shapiro et al. 1989b, Vrieling et al. 1993a). The secondary antibody could be conjugated to a molecule other than a fluorochrome, e.g. an enzyme or a radioisotope. This would enable the assay to be run as an immunodot blot, enzyme-linked immunosorbent assay (ELISA), or radioimmunoassay (RIA), increasing the throughput of samples via automation. Finally, the success shown by these polyclonal antibodies suggests that it may be worthwhile to develop monoclonal antibodies against $P$. pungens, although this approach may also have some disadvantages, e.g. a loss of sensitivity (Campbell et al. 1988).

There are numerous benefits of an immunochemical assay capable of detecting and distinguishing toxic and nontoxic forms of Pseudonitzschia pungens. Such a technique will: (1) provide a research tool to carry out laboratory experiments, e.g. on the competitive growth of the 2 forms of $P$. pungens growing in the same culture flask; (2) enable toxic phytoplankton monitoring programs (including those currently run by the Department of Fisheries and Oceans, Canada) to more rapidly and accurately determine the presence of toxic and nontoxic forms of $P$. pungens; (3) allow a comparison of $P$. pungens cells in natural samples collected from different oceans of the world to evaluate the potential for those waters to have an outbreak of domoic acid poisoning, given a sufficient increase in P. pungens cell concentration; and (4) eventually lead to the development of easy-to-use 'test kits' that could be used by aquaculturalists, regulatory agencies, and others concerned with determining the presence of the toxic form of $P$. pungens.

It is clear that the international scientific community and government regulatory agencies are becoming increasingly aware that the problem of harmful algal blooms, i.e. both the number of phytoplankton species implicated and the number of reported events, are spreading globally (Anderson 1989, Smayda 1990). The use of immunology as a tool for studying the presence, identity and distribution of toxic algae will likely increase as concern about their harmful impact on human health and the economy increases. 
Acknowledgements. We thank $M$. Laflamme for excellent technical assistance and timely advice. G. A. Fryxell, D. M. Jacobson, T A. Villareal, P. E. Hargraves, K. E. Pauley, D. J. Douglas and L. Maranda kindly provided preserved samples of phytoplankton for testing from their culture collections. K. E. Pauley and J. C. Smith carried out scanning electron microscopy on several of the Pseudonitzschia pungens clones, using facilities at the Institute for Marine Biosciences, National Research Council of Canada, Halifax, Nova Scotia. This work was supported in part by grant OCE89-11226 (to D.M.A.) from the U.S. National Science Foundation. Contribution no. 8235 from the Woods Hole Oceanographic Institution.

\section{LITERATURE CITED}

Anderson, D. M. (1989). Toxic algal blooms and red tides: a global perspective. In: Okaichi, T., Anderson, D. M. Nemoto, T. (eds.) Red tides: biology, environmental science, and toxicology. Elsevier, New York, p. 11-16

Anderson, D. M., Kulis, D. M., Cosper, E. M. (1988). Immunofluorescent detection of the brown tide organism, Aureococcus anophagefferens. In: Cosper, E. M., Bricelj, V. M. Carpenter, E. J. (eds.) Novel plankton blooms: causes and impacts of recurrent brown tides and other unusual blooms. Springer-Verlag, New York, p. 213-228

Bates, S. S., Bird, C. J., de Freitas, A. S. W., Foxall, R., Gilgan, M., Hanic, L. A., Johnson, G. R., McCulloch, A. W. Odense, P., Pocklington, R., Quilliam, M. A., Sim., P. G., Smith, J. C., Subba Rao, D. V., Todd, E. C. D., Walter, J. A. Wright, J. L. C. (1989). Pennate diatom Nitzschia pungens as the primary source of domoic acid, a toxin in shellfish from eastern Prince Edward Island, Canada. Can. J. Fish. Aquat. Sci. 46: 1203-1215

Bates, S. S., de Freitas, A. S. W., Milley, J. E., Pocklington, R., Quilliam, M. A., Smith, J. C., Worms, J. (1991). Controls on domoic acid production by the diatom. Nitzschia pungens f. multiseries in culture: nutrients and irradiance. Can J. Fish. Aquat. Sci. 48: 1.136-11.44

Buck, K. R., Uttal-Cooke, L., Pilskaln, C. H., Roelke, D. L., Villac, M. C., Fryxell, G. A., Cifuentes, L., Chavez, F. P. (1992). Autecology of the diatom Pseudonitzschia australis Frenguelli, a domoic acid producer, from Monterey Bay, California. Mar. Ecol. Prog. Ser. 84: 293-302

Campbell, L. (1988). Identification of marine chroococcoid cyanobacteria by immunofluorescence. In: Yentsch, C. M., Mague, F. C., Horan, P. K. (eds.) Immunochemical approaches to coastal, estuarine and oceanographic questions. Springer-Verlag, New York, p. 208-229

Campbell, L., Carpenter, E. J. (1987). Charactenzation of phycoerythrin-containing Synechococcus spp. populations by immunofluorescence. J Plankton Res. 9: $1167-1181$

Campbell, L., Carpenter, E., lacono, V. J. (1983). Identification and enumeration of marine chroococcoid cyanobacteria by immunofluorescence. Appl environ. Microbiol 46 : $553-559$

Campbell, L., Shapiro, L. P., Haugen, E. M., Morris, L. (1988). Immunochem.cal approaches to the identification of the ultraplankton: assets and limitations. In: Cosper, E. M., Bricelj, V M.. Carpenter, E. J. (eds.) Novel plankton blooms: causes and impacts of recurrent brown tides and other unusual blooms. Springer-Verlag, New York, p. $39-56$

Cucci, T. L., Robins, D. (1988). Flow cytometry and immunofluorescence in aquatic sciences. In: Yentsch, C. M.,
Mague, F. C., Horan, P. K. (eds.) Immunochemical approaches to coastal, estuarine and oceanographic questions. Springer-Verlag, New York, p. 184-193

Dickey, R. W., Fryxell, G. A., Grande, H. R., Roelke, D. (1992). Detection of the marine toxins okadaic acid and domoic acid in shellfish and phytoplankton in the Gulf of Mexico. Toxicon 30: $355-359$

Fliermans, C. B., Schmidt, E. L. (1977). Immunofluorescence for autecological study of a unicellular bluegreen alga. J. Phycol. 13: 364-368

Fritz, L., Quilliam, M. A., Wright, J. L. C., Beale, A., Work, T M. (1992). An outbreak of domoic acid poisoning attributed to the pennate diatom Pseudonitzschia australis. J. Phycol. 28: 439-442

Fryxell, G. A., Garza, S. A., Roelke, D. L. (1991). Auxospore formation in an Antarctic clone of Nitzschia subcurvata Hasle. Diatom Res. 6: 235-245

Fryxell, G. A., Reap, M. E., Valencic, D. L. (1990). Nitzschia pungens Grunow f. multiseries Hasle: observations of a known neurotoxic diatom. Beih. Nova Hedwigia 100: $171-188$

Garrison, D. L., Conrad, S. M., Eilers, P. P., Waldron, E. M. (1992). Confirmation of domoic acid production by Pseudonitzschia australis (Bacillariophyceae) cultures. J. Phycol. 28: 604-607

Goldman, M. (1968). Fluorescent antibody methods. Academic Press, New York, p. 1-303

Guillard, R. R. L., Ryther, J. H. (1962). Studies of marine planktonic diatoms. I. Cycletella nana Hustedt, and Detonula confervacea (Cleve) Gran. Can. J. Microbiol. 8: 229-239

Hasle, G. R. (1965). Nitzschia and Fragilariopsis species studied in the light and electron microscopes. II. The group Pseudonitzschia. Skr. norske Vidensk-Akad. Oslo, Mat.-Nat. KI. N.S. 18: 1-45

Hasle, G. R. (1993). Nomenclatural notes on marine planktonic diatoms. The family Bacillariaceae. Beih. Nova Hedwigia 106: $315-321$

Hiroishi, S., Uchida, A., Nagasaki, K., Ishida, Y (1988). A new method for identification of inter-and intra-species of the red tide algae Chattonella antiqua and Chattonella marina (Raphidophyceae) by means of monoclonal antibodies. J. Phycol 24: 442-444

Maranda, L., Wang, R., Masuda, K., Shimizu, Y (1990). Investigation of the source of domoic acid in mussels. In: Granéli, E., Sundström, B., Edler, L., Anderson, D. M. (eds.) Toxic marine phytoplankton. Elsevier, Inc., New York, p. 300-304

Martin, J. L., Haya, K., Burridge, L. E., Wildish, D. J. (1990). Nitzschia pseudodelicatissima - a source of domoic acid in the Bay of Fundy, eastern Canada. Mar. Ecol. Prog Ser. 67: $177-182$

Mizuno, M. (1987). Morphological variation of the attached diatom Cocconeis scutellum (Bacillariophyceae). J. Phycol 23: $591-597$

Nagasaki, K., Uchida, A., Ishida, Y (1991). A monoclonal antibody which recognizes the cell surface of red tide alga Gymnodinium nagasakiense. Nippon Suisan Gakk. 57: $1211-1214$

Pocklington, R., Milley, J. E., Bates, S. S., Bird, C. J., de Freitas, A. S. W., Quilliam, M. A. (1990). Trace determınation of domoic acid in seawater and phytoplankton by high-performance liquid chromatography of the fluorenylmethoxycarbonyl. (FMOC) derivative. Int. J. environ. analyt Chem. 38: 351-368

Sako, Y., Kim, C. H., Ishida, Y (1992). Mendelian inheritance of paralytic shellfish poisoning toxin in the marine 
dinoflagellate Alexandrium catenella. Biosci. Biotech. Biochem. 56: 692-694

Schmid, A.-M. (1979). Influence of environmental factors on the development of the valve in diatoms. Protoplasma 99: 99-115

Scholin, C. A., Anderson, D. M. (1993). Population analysis of toxic and nontoxic Alexandrium species using ribosomal RNA signature sequences. In: Smayda, T. J., Shimizu, Y (eds.) Toxic phytoplankton blooms in the sea. Elsevier, Amsterdam, p. 95-102

Seguel, M. R. (1991). Interactive effects of temperature-light and temperature-salinity on growth of five phytoplanktonic species isolated from a shallow-water embayment of Nova Scotia. M.Sc thesis, Acadia University, Wolfville, NS

Shapiro, L., Campbell, L., Haugen, E. M. (1989a). Immunochemical recognition of phytoplankton species. Mar. Ecol. Prog. Ser. 57: 219-224

Shapiro, L. P., Haugen, E. M., Keller, M. D., Bidigare, R. R., Campbell, L., Guillard, R. R. L. (1989b). Taxonomic affinities of marine coccoid ultraplankton: a comparison of immunochemical surface antigen cross-reactions and HPLC chloroplast pigment signatures. J. Phycol. 25: 794-797

Smayda, T. J. (1990). Novel and nuisance phytoplankton blooms in the sea: evidence for a global epidemic. In: Granéli, E., Sundström, B., Edler, L., Anderson, D. M. (eds.) Toxic marine phytoplankton. Elsevier, Inc., New York, p. $29-40$

Smith, J. C., Odense, P., Angus, R., Bates, S. S., Bird, C. J., Cormier, P., de Freitas, A. S. W., Léger, C., O'Neil, D., Pauley, K., Worms, J. (1990). Variation in domoic acid levels in Nitzschia species: implications for monitoring programs. Bull. Aquacult. Ass. Can. 90-4: 27-31

Subba Rao, D. V., Wohlgeschaffen, G. (1990). Morphological variants of Nitzschia pungens Grunow t. multiseries Hasle. Botanica mar. 33: 545-550

Takano, H., Kikuchi, K. (1985). Anomalous cells of Nitzschia pungens Grunow found in eutrophic marine waters. Diatom 1:18-20

This article was presented by D. A. Caron, Woods Hole, Massachusetts, USA
Todd, E. C. D. (1993). Domoic acid and Amnesic Shellfish Poisoning - a review. J. Food Protect. 56: 69-83

Uchida, A., Nagasaki, K., Hiroishi, S., Ishida, Y (1989). The application of monoclonal antibodies to an identification of Chattonella marina and Chattonella antiqua. Nippon Suisan Gakk. 55: 721-725

Vrieling, E. G., Draaijer, A., van Zeijl, W. J. M., Peperzak, L., Gieskes, W. W. C., Veenhuis, M. (1993a). The effect of labeling intensity, estimated by real-time confocal laser scanning microscopy, on flow cytometric appearance and identification of immunochemically labeled marine dinoflagellates. J. Phycol. 29: 180-188

Vrieling, E. G., Gieskes, W. W. C., Colijn, F., Hofstraat, J. W., Peperzak, L., Veenhuis, M. (1993b). Immunochemical identification of toxic marine algae: first results with Prorocentrum micans as test organism. In: Smayda, T. J., Shimizu, Y. (eds.) Toxic phytoplankton blooms in the sea. Elsevier Science Publishers, Amsterdam, p. 925-931

Ward, B. B. (1982). Oceanic distribution of ammoniumoxidizing bacteria determined by immunofluorescent assay. J. mar. Res. 40: 1155-1172

Ward, B. B., Perry, M. J. (1980). Immunofluorescent assay for the marine ammonium-oxidizing bacterium Nitrosococcus oceanus. Appl. environ. Microbiol. 39: 913-918

Wood, A. M., Leatham, T (1992). The species concept in phytoplankton ecology. J. Phycol. 28: 723-729

Wood, A. M., Shapiro, L. M. (eds.) (1993). Domonic acid - final report of the workshop. Oregon Sea Grant, Oregon State University, Corvallis

Wright, J. L. C., Boyd, R. K., de Freitas, A. S. W., Falk, M., Foxall, R. A., Jamieson, W. D., Laycock, M. V., McCulloch, A. W., McInnes, A. G., Odense, P., Pathak, V., Quilliam, M. A., Ragan, M. A., Sim, P. G., Thibault, P., Walter, J. A., Gilgan, M., Richard, D. J. A., Dewar, D. (1989). Identification of domoic acid, a neuroexcitatory amino acid, in toxic mussels from eastern Prince Edward Island. Can. J. Chem. 67: $481-490$

Manuscript first received: December 11, 1992

Revised version accepted: June 22, 1993 